\title{
Influence of different counterions on gemini surfactants with polyamine platform as corrosion inhibitors for stainless steel AISI 304 in $3 \mathrm{M} \mathrm{HCI}$
}

DOI:

10.1016/j.molliq.2018.07.120

\section{Document Version}

Accepted author manuscript

Link to publication record in Manchester Research Explorer

Citation for published version (APA):

Pakiet, M., Kowalczyk, I. H., Leiva Garcia, R., Akid, R., \& Brycki, B. E. (2018). Influence of different counterions on gemini surfactants with polyamine platform as corrosion inhibitors for stainless steel AISI 304 in $3 \mathrm{M} \mathrm{HCl}$. Journal of Molecular Liquids, 268, 824-831. https://doi.org/10.1016/j.molliq.2018.07.120

\section{Published in:}

Journal of Molecular Liquids

\section{Citing this paper}

Please note that where the full-text provided on Manchester Research Explorer is the Author Accepted Manuscript or Proof version this may differ from the final Published version. If citing, it is advised that you check and use the publisher's definitive version.

\section{General rights}

Copyright and moral rights for the publications made accessible in the Research Explorer are retained by the authors and/or other copyright owners and it is a condition of accessing publications that users recognise and abide by the legal requirements associated with these rights.

\section{Takedown policy}

If you believe that this document breaches copyright please refer to the University of Manchester's Takedown Procedures [http://man.ac.uk/04Y6Bo] or contact uml.scholarlycommunications@manchester.ac.uk providing relevant details, so we can investigate your claim.

\section{OPEN ACCESS}




\section{Accepted Manuscript}

Influence of different counterions on gemini surfactants with polyamine platform as corrosion inhibitors for stainless steel AISI 304 in $3 \mathrm{M} \mathrm{HCl}$

Marta Pakiet, Iwona Kowalczyk, Rafael Leiva Garcia, Robert Akid, Bogumił Brycki

PII: S0167-7322(18)31343-6

DOI: doi:10.1016/j.molliq.2018.07.120

Reference: MOLLIQ 9441

To appear in: Journal of Molecular Liquids

Received date: 14 March 2018

Revised date: 22 June 2018

Accepted date: 31 July 2018

Please cite this article as: Marta Pakiet, Iwona Kowalczyk, Rafael Leiva Garcia, Robert Akid, Bogumił Brycki , Influence of different counterions on gemini surfactants with polyamine platform as corrosion inhibitors for stainless steel AISI 304 in $3 \mathrm{M} \mathrm{HCl}$. Molliq (2018), doi:10.1016/j.molliq.2018.07.120

This is a PDF file of an unedited manuscript that has been accepted for publication. As a service to our customers we are providing this early version of the manuscript. The manuscript will undergo copyediting, typesetting, and review of the resulting proof before it is published in its final form. Please note that during the production process errors may be discovered which could affect the content, and all legal disclaimers that apply to the journal pertain. 


\title{
Influence of different counterions on gemini surfactants with polyamine platform as corrosion inhibitors for stainless steel AISI 304 in $3 \mathrm{M} \mathrm{HCl}$
}

\author{
Marta Pakiet ${ }^{1,2^{*}}$, Iwona Kowalczyk ${ }^{1}$, Rafael Leiva Garcia ${ }^{2}$, Robert Akid ${ }^{2}$, Bogumił Brycki ${ }^{1}$ \\ ${ }^{1}$ Laboratory of Microbiocides Chemistry, Faculty of Chemistry, Adam Mickiewicz University, \\ Umultowska 89b, 61-614 Poznań, Poland \\ ${ }^{2}$ School of Materials, University of Manchester, Manchester, M139PL, UK \\ *corresponding author \\ e-mail address: mpakiet@ amu.edu.pl
}

\begin{abstract}
The corrosion inhibition efficiency of two cationic gemini surfactants with different counterions with polyamine platform on AISI 304 stainless steel in $3 \mathrm{M} \mathrm{HCl}$ was investigated by polarisation measurements and electrochemical impedance spectroscopy (EIS). The surface of the samples was characterised before and after the corrosion experiments using scanning electron microscopy (SEM) and confocal laser scanning microscopy (CLSM). The results showed that the effectiveness of corrosion inhibiton depends on counterion belongs to surfactant molecule. The dimeric surfactant with the iodine counterion out-performs its bromine counterpart with respect to providing corrosion inhibition of stainless steel, in $3 \mathrm{M}$ $\mathrm{HCl}$. In the present study, the Langmuir adsorption isotherm was found to be suitable parameter for the correlating the experimental results with a possible mechanism of protection. In the case of two tested compounds the highest inhibition efficiency was found around the critical micelle concentration. Critical micelle concentration was determined using conductometric titration.
\end{abstract}

\section{Highlights}

- New surfactants with polyamine platform were synthesized.

- Critical Micelle Concentration was determined for two gemini surfactants with different counterion.

- Polarisation and EIS measurement were used for analysis.

- The surface of AISI 304 specimen was characterized using SEM and CLSM.

\section{Keywords}

Surfactants, Stainless steel, CMC, corrosion inhibitors 


\section{Introduction}

The concept of "Gemini surfactants" appears for the first time in literature in 1991 [1]. However, the real interest in this group of compounds took place a few years later when it was proven that gemini surfactants have superior surface-active properties over that of their monomeric analogues [2-4]. Gemini surfactants are composed of two molecules, notably, conventional monomeric surfactants that are connected together by a spacer [5]. The spacer present between the hydrophilic 'heads' of the gemini surfactants affects significantly the value of the critical micelle concentration (CMC), and, hence the surface activity [3,6-9]. In the case of the cationic surfactants of double flexible hydrophobic polymethylene $\left(\mathrm{CH}_{2}\right)$, CMC decreases with the amount of methylene groups $\left(-\mathrm{CH}_{2}-\right)$ [1]. This is probably due to the unfavourable orientation of the hydrophobic spacer in contact with the aqueous phase [10].

One of the most important parameters defining the properties of surfactants in aqueous solution is the CMC. The stability of spherical micelles is due to the mutual compensation of factors, such as: the attraction between the alkyl chain and repulsion resulting from the electrostatic interactions between polar groups hydrated localised on the surface of the micelles formed.

Due to these properties and the possibility of modifying their structure, gemini surfactants have, potentially, many industrial applications such as cleaning agents, detergents, microbiocides, solubilisation agents and corrosion inhibitors [11-13]. This latter application is one of the most practical approaches for the protection of metals in acidic media[14]. Inhibitors replace water from the metal surface, interacting with anodic or cathodic reaction sites to inhibit redox reactions [15-19].

Corrosion inhibition efficacy from surfactant molecules is related to the surfactant's ability to aggregate in solution. Understanding the factors that affect aggregation as well as the state of aggregation of surfactant molecules on metal surfaces is, therefore, an important prerequisite to understanding corrosion inhibition by surfactant molecules. A key parameter that reflects the performance of amphiphile structures as corrosion inhibitors is that of the CMC value. Below the CMC value, individual molecules begin to adsorb on the metal surface. When the CMC concentration is reached, micelles are formed in the electrolyte and the surface of the material is covered with a monolayer. Any addition of surfactant to the solution does not significantly increase the efficiency of the surfactant inhibitor as the entire surface of the material is already saturated with molecules. Rather, it merely serves to create additional micelles and to increase the number of layers formed on the metal surface.

Important aspect of this research is using stainless steel. Stainless steels are widely used in industry as construction materials, because of their good mechanical properties and corrosion resistance [20-22].

Currently, there are numerous studies in which surfactant structures are evaluated as corrosion inhibitors, however, what does not appear too much information about the influence of the molecule counterion on the adsorption process on the surface of metal [23-25]. Counterion plays an important role during the adsorption process into metals or other surfaces. The 
presented studies confirm that gemini surfactants not only have lower CMC relative to their monomeric analogues but they also inhibit more effectively corrosion even at low concentrations [26]. In case of gemini suractants functionalised by oxygen atom the highest inhibition efficiency was reached around CMC concentration[24]. Proposed novel cationic gemini surfactants contain heteroatom in spacer which significantly affect on corrosion inhibition mechanism.

Therefore the aim of this work is to investigate, using electrochemical impedance spectroscopy (EIS) and polarisation measurements, the corrosion inhibition effect of different counterions on a designated surfactant, Figure 1, on a stainless steel in $3 \mathrm{M} \mathrm{HCl}$ solution. The effects of counterion concentration on inhibition efficiency was also studied. The surface of the samples was characterised before and after the corrosion experiments using scanning electron microscopy (SEM) and confocal laser scanning microscopy (CLSM).

\section{Experimental methods and materials}

\subsection{Synthesis of cationic surfactants}

Cationic surfactants were prepared by reaction of different alkyl halides, notably, dodecyl bromide and dodecyl iodine respectively with appropriate amounts of 3,3- Iminobis $(N, N-$ dimethylpropylamine) with the molar ratio 2:1. The reactants were allowed to reflux in acetonitrile for $30 \mathrm{~h}$, following which the solution was left to cool down to room temperature. The products were crystallised from acetonitrile with the addition of diethyl ether and then dried over $\mathrm{P}_{4} \mathrm{O}_{10}$. The chemical structure of these compounds is presented in Figure 1.

\subsection{Spectroscopic characterisation of gemini surfactants}

Nuclear Magnetic Resonance (NMR) spectra were measured with a Spectrometer NMR Varian Mercury $300 \mathrm{MHz}$ (Oxford, UK), operating at 300.07 and $75.4614 \mathrm{MHz}$ for ${ }^{1} \mathrm{H}$ and ${ }^{13} \mathrm{C}$, respectively. Typical conditions for the proton spectra were: pulse width $32^{\circ}$, acquisition time $5 \mathrm{~s}$, FT size $32 \mathrm{~K}$ and digital resolution $0.3 \mathrm{~Hz}$ per point, and for the carbon spectra: pulse width $60^{\circ}$, FT size $60 \mathrm{~K}$ and digital resolution $0.6 \mathrm{~Hz}$ per point, the number of scans varied from 1200 to 10,000 per spectrum. The ${ }^{13} \mathrm{C}$ and ${ }^{1} \mathrm{H}$ chemical shifts were measured in $\mathrm{CDCl}_{3}$ relative to an internal standard of TMS.

\subsection{Conductivity Measurement}

Conductivity measurements were carried out using a conductivity meter (Conductivity Meter CO 300, VWR, Poland) with 2-pole measuring cell (Ø $12 \mathrm{~mm}$, stainless steel). The instrument was calibrated by standard $\left(147 \mu \mathrm{S} / \mathrm{cm}\right.$ in $\left.25^{\circ} \mathrm{C}\right)$. Equipment was initially calibrated by standard $\mathrm{KCl}$ solutions. Deionised double-distilled water was used in all experimental work with a specific conductivity value of $1-2 \times 10^{-6} \mathrm{~S} / \mathrm{cm}$. 


\subsection{Stainless steel}

The specimen used for the electrochemical tests was stainless steel, grade AISI 304. The chemical composition of the working electrode (in weight \%) was: $\mathrm{Cr} 17-20, \mathrm{Mn} 2$, Ni 8-11, $\mathrm{C} 0.08$, Fe balance. Working electrodes $(2.5 \times 2.5 \mathrm{~cm})$ were prepared by covering the sample in stopping lacquer to ensure that only an area of $1 \mathrm{~cm}^{2}$ was exposed to the electrolyte.

\subsection{Electrolytes.}

$3 \mathrm{M} \mathrm{HCl}$ solutions were prepared by dilution of analytical grade $\mathrm{HCl}(32 \%)$ with deionised water. Different concentrations of inhibitors were added to the prepared $3 \mathrm{M} \mathrm{HCl}$ solutions. All experiments were carried out at room temperature.

\subsection{Electrochemical measurements}

Electrochemical tests were carried out using a conventional three-electrode cell with a platinum counter electrode, a saturated calomel electrode (SCE) as a reference electrode and a working electrode of stainless steel AISI 304 plate. The test was repeated at least three times. All polarisation curves were recorded using a potentiostat (Versastat ${ }^{\mathrm{TM}}$ 4.0). Individual separate anodic and cathodic potentiodynamic polarisation measurements were obtained by changing the electrode potential automatically from (cathodic) OCP to $-300 \mathrm{mV}$ vs the OCP and (anodic) OCP to $+300 \mathrm{mV}$ vs OCP, respectively, with a scan rate $0.5 \mathrm{mV} \mathrm{s}^{-1}$. Linear polarisation resistance measurements (LPR) were obtained by scanning the potential from -20 to $20 \mathrm{mV}$ versus the measured OCP with a scan rate of $10 \mathrm{mV} \mathrm{min}{ }^{-1}$. Electrochemical impedance spectroscopy (EIS) measurements were conducted using a potentiostat (Versastat ${ }^{\mathrm{TM}} 4.0$ ). Impedance spectra were obtained over a frequency range of $100 \mathrm{kHz}$ to 10 $\mathrm{mHz}$ with a $10 \mathrm{mV}$ sine wave as the excitation signal at open circuit potential.

\subsection{Surface morphology}

The morphology of the 304 stainless steel surfaces before and after $24 \mathrm{~h}$ corrosion tests were studied by scanning electron microscopy (SEM) using a FEI Quanta 200 operating at $20 \mathrm{kV}$ and different magnifications. The roughness of surface, as an indicator of corrosion attack, was studied using a Keyence VK-X200K 3D Confocal Laser Scanning Microscope.

\section{Results and discussion}

\subsection{Characterisation of gemini surfactants}

The chemical structure of the synthesised compounds was characterised by ${ }^{1} \mathrm{H}$ and ${ }^{13} \mathrm{C}$ NMR.

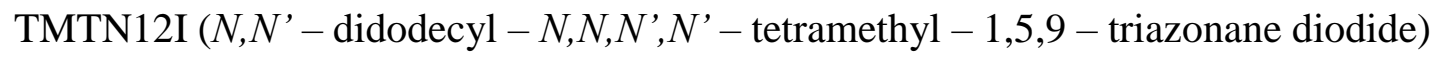
Yield: $95 \%$. ${ }^{1} \mathrm{H}$ NMR (Varian $\left.400 \mathrm{MHz}, \mathrm{CDCl}_{3}\right): 0.88 \mathrm{ppm}(6 \mathrm{H}, \mathrm{t}), 1.26 \mathrm{ppm}(36 \mathrm{H}, \mathrm{m}), 1.77$ $(4 \mathrm{H}, \mathrm{m}), 1.96(4 \mathrm{H}, \mathrm{m}), 2.82(4 \mathrm{H}, \mathrm{m}), 3.36(12 \mathrm{H}, \mathrm{s}), 3.47(4 \mathrm{H}, \mathrm{m}), 3.99(4 \mathrm{H}, \mathrm{t}) .{ }^{13} \mathrm{C} \mathrm{NMR}$ (Varian $400 \mathrm{MHz}, \mathrm{CDCl}_{3}$ ), 64.73, 63.94, 51.16, 45.74, 31.84, 29.54, 29.42, 29.37, 29.27, 29.20, 26.25, 23.05, 22.91, 22.62, 14.06. 
TMTN12Br $\left(N, N^{\prime}\right.$ - didodecyl $-N, N, N^{\prime}, N^{\prime}-$ tetramethyl - 1,5,9 - triazonane dibromide $)$ Yield: $96 \%{ }^{1} \mathrm{H}$ NMR (Varian $\left.400 \mathrm{MHz}, \mathrm{CDCl}_{3}\right)$ : $0.86 \mathrm{ppm}(6 \mathrm{H}, \mathrm{t}), 1.26 \mathrm{ppm}(36 \mathrm{H}, \mathrm{m}), 1.77$ $(4 \mathrm{H}, \mathrm{m}), 1.81(4 \mathrm{H}, \mathrm{m}), 2.58(4 \mathrm{H}, \mathrm{m}), 3.32(12 \mathrm{H}, \mathrm{s}), 3.45(4 \mathrm{H}, \mathrm{m}), 3.97(4 \mathrm{H}, \mathrm{t}) .{ }^{13} \mathrm{C} \mathrm{NMR}$ (Varian $400 \mathrm{MHz}, \mathrm{CDCl}_{3}$ ) 65.74, 61.89, 50.96, 44.56, 31.86, 29.59, 29.50, 29.46, 29.30, $29.24,26.34,22.88,22.63,20.01,14.06$.

\subsection{CMC determination}

$\mathrm{CMC}$ is one of the most important physicochemical properties describing the aggregation of gemini surfactants in aqueous solutions. CMC values were obtained by plotting conductivity against surfactant concentration. The conductometric titration was repeated at least three times. This type of plot provides two different slopes before and after the micellisation regions. The corresponding critical micelle concentration value was determined from the location of the intersection point of these two slopes. Electrical conductivity values were used to determine the degree of micelle ionisation $\left(\alpha=S_{2} / S_{1}\right)$, where $S_{1}$ and $S_{2}$ are the slopes below and above the CMC value in the curve of specific conductivity against surfactant concentration [27,28]. Additionally, the value of the slope of linear regions above and below the CMC gives an estimate of the counterion binding parameter, $\beta$. This parameter evaluates the counterions that are contained in the Stern layer to counterbalance the electrostatic force that contrast aggregate formation. The formation of micelles is not only affected by the electrostatic force, but also by the influence of other intermolecular forces, such as van der Waals force, the repulsion between the head groups with the same charge, hydrogen bonding interaction between the hydrophilic part and the aqueous solution [29]. The standard Gibbs energy of micellisation ( $\Delta \mathrm{G}^{\circ}$ mic $)$ indicates if the process of forming micelles is spontaneous and can be calculated using the following expression (1) [30]:

$$
\Delta \mathrm{G}_{m i c}^{\circ}=\mathrm{RT}\left(\frac{1}{2}+\beta\right) \ln \mathrm{CMC}-\left(\frac{\mathrm{RT}}{2}\right) \ln 2
$$

where $\beta$ is the fraction of charges of micellised univalent surfactant ions neutralised by micelle-bound univalent counterions $(\beta=1-\alpha)$, the CMC is expressed in $\mathrm{mol} / \mathrm{dm}^{3}, \mathrm{~T}$ is the temperature in Kelvin $(\mathrm{K})$ and $\mathrm{R}$ is the gas constant.

A comparison of the results obtained is presented in Table 1

The standard Gibbs energy of micellisation obtained for both inhibitors (TMTN12Br and TMTN12I) is negative, which indicates that the process of micelle creation is spontaneous $[31,32]$. Moreover, the standard Gibbs energy parameter is lower for the structure containing iodine as the counterion.

\subsection{Open circuit potential}

Open circuit potential measurements were obtained at room temperature for the stainless steel samples immersed in $3 \mathrm{M} \mathrm{HCl}$ without (blank) and with the addition of different concentrations of gemini surfactants. Figure 3 shows the trend in the OCP with time. 
The AISI 304 specimen potential was $-344 \mathrm{mV}_{\text {SCE }}$ after $1 \mathrm{~h}$ and increased to $-316 \mathrm{mV}_{\text {SCE }}$ after $24 \mathrm{~h}$ of immersion. The addition of TMTN12I (3mM) changed the potential from -225 $\mathrm{mV}_{\mathrm{SCE}}$ to $-221 \mathrm{mV}_{\mathrm{SCE}}$ after $24 \mathrm{hr}$, being very stable during the whole immersion test. On changing the concentration to $1.5 \mathrm{Mm}$, for the same compound the potential changed slightly, notably. after $1 \mathrm{~h}$ it was $-252 \mathrm{mV}_{\mathrm{SCE}}$, increasing to $-225 \mathrm{mV}_{\mathrm{SCE}}$ after $24 \mathrm{~h}$. Figure 3 presents the OCP trends for the two compounds with different counterions and concentrations. For both counterion concentrations, the potential is more positive for TMTN12I compared with TMTN12Br.

\subsection{Potentiodynamic polarisation measurement}

Figure 4 and 5 present the anodic and cathodic polarisation curves for samples immersed in solutions containing $3 \mathrm{M} \mathrm{HCl}$ in the absence and presence of the most efficient concentration of TMTN12Br and TMTN12I (see Table 2). Comparing these results with the polarisation curves obtained with the blank solution, it can be observed that both the anodic and the cathodic current densities decrease in the presence of the surfactants, indicating that these compounds suppressed both the anodic and the cathodic reactions through adsorption on the stainless steel surface.

The values of corrosion current density $\left(\mathrm{i}_{\text {corr }}\right)$ were calculated from the transformation of the Stern-Geary equation [33]

$i_{\text {corr }}=\frac{\beta_{a} \beta_{c}}{2.303\left(\beta_{a}+\beta_{c}\right) R_{p}}$

$\beta_{\mathrm{a}}, \beta_{\mathrm{c}}-$ slope coefficients of the anode and cathode segment of the Tafel chart [V / dec] respectively, $R_{p}$ - polarisation resistance $\left[\Omega \mathrm{cm}^{2}\right.$ ] [5].

Corrosion rate was calculated using the following equation [34]:

$C R=\frac{i_{c o r r} A w 10 * 3.15 * 10^{7}}{n F d}$

where $i_{\text {corr }}$ is the current density $\left[\mathrm{A} \mathrm{cm}^{-2}\right], \mathrm{Aw}-$ Atomic weight $\left(56 \mathrm{~g} \mathrm{~mol}^{-1}\right)$ for iron, $\mathrm{F}-$ Faraday's constant $\left(96,500 \mathrm{C} \mathrm{mol}^{-1}\right), \mathrm{n}=2, \mathrm{~d}$ - density of stainless steel $\left(7.93 \mathrm{~g} \mathrm{~cm}^{-3}\right), 3.15$ $* 10^{7}$ - one year in seconds and 10 is a conversion factor to obtain the results in mM. The current density was calculated from equation (2).

The corrosion inhibition efficiency was calculated using the following equation[35-37]:

$I E(\%)=\frac{i_{0 c o r r}-i_{\text {corr }}}{i_{0 c o r r}} x 100 \%$ 
Where $\mathrm{i}_{0 \text { corr }}$ and $\mathrm{i}_{\text {corr }}$ are the corrosion current density without and with surfactant inhibitors in solution respectively.

Lower values of corrosion current density and higher values of the polarisation resistance of the sample indicate lower susceptibility to corrosion. Tafel's slopes are parallel to the polarization curves registered for the sample reference indicating that the mechanism of corrosion processes has not been changed, and the tested inhibitors adsorb on cathodic and anodic sites of active stainless steel surfaces. Studied quaternary ammonium salts act as mixed anodic-cathodic corrosion inhibitors [38].

All of the cationic surfactants tested showed the best performance at concentrations close to the critical micellar concentration. The initial increase in surfactant concentration leads to an increase in IE\% until a maximum (close to the CMC value) is reached [32, 33]. A further increase in concentration for the gemini surfactants studied here, does not affect the effectiveness of corrosion inhibition, indicating that a protective layer has been formed on the stainless steel surface and the addition of inhibitor molecules leads to the formation of micelles that have no significant effect on the corrosion parameters.

With regard to the corrosion rate (CR) value after $24 \mathrm{~h}$ immersion, immersion without an inhibitor is $20.77 \mathrm{~mm} /$ year, compared to $0.28 \mathrm{~mm} /$ year for $1.5 \mathrm{Mm}$ of TMTN12I and 0.51 $\mathrm{mm} /$ year for $3 \mathrm{mM}$ TMTN12Br.

\subsection{Electrochemical impedance spectroscopy}

The Nyquist plots for stainless in $3 \mathrm{M} \mathrm{HCl}$ solution with and without various concentrations of gemini surfactants are shown in Figure 6. The radius of each semicircle corresponds to the corrosion resistance, the greater the semicircle the higher the resistance [41]. For all concentrations the semicircle radius is significantly greater than the radius of the reference sample immersed in $3 \mathrm{M} \mathrm{HCl}$ without inhibitor. Moreover, the diameter of the semicircle increases gradually with an increase of the surfactant concentration from $1.5 \mathrm{mM}$ to $3 \mathrm{mM}$ for both TMTN12Br and TMTN12I.

The impedance in the EIS test increased because the degree of coverage increase at higher surfactant concentration. In addition, significant differences in the same compounds were distinguished. For example, for TMTN12Br at $1.5 \mathrm{mM}$ and $3 \mathrm{mM}$ concentration the radius of semicircle is almost the same. It means that when concentration was increased to a value higher than CMC, the extent of corrosion inhibition is not increased. Furthermore, molecules attached to the metal surface and addition/increasing of concentration didn't extend yield of the inhibition process. In CMC the given corrosion inhibitor begins to exhibit the highest corrosion inhibiting efficiency.

The experimental data was fitted to an equivalent circuit model using the $\mathrm{ZView} 2^{\oplus}$ programme. The proposed equivalent circuit consist of a solution resistance (R1), a constant phase element 
(CPE1), related to the capacitive behavior of the inhibitor film formed on the surface of the metal in parallel with a resistance (R2) which is related to the interface between the solution and the metal surface.

Inhibition efficiency (IE) was calculated according to the following equation $(5)[42,43]$

$I E \%=\frac{R_{0 c t-R_{c t}}}{R_{0 c t}} 100 \%$

where $R_{0 c t}$ and $R_{c t}$ are the charge transfer resistance values without and with inhibitor addition for stainless steel in $3 \mathrm{M} \mathrm{HCl}$, respectively.

Charge transfer $\left(\mathrm{R}_{\mathrm{ct}}\right)$ values increase with increasing inhibitor concentration and reach the highest values around CMC. The double layer capacitance values decrease in the presence of the tested inhibitors from 7296.42 to $220.39 \mu \mathrm{F} / \mathrm{cm}^{2}$ for $3 \mathrm{mM}$ TMTN12I. This may be related to an increase in the thickness of the adsorbed film as more molecules join onto the film. In the case of $0.015 \mathrm{mM}$ TMTN12I, the capacitance value $615.98 \mu \mathrm{F} / \mathrm{cm}^{2}$ may be due to the fact that, at this concentration, there is a less dense surfactant layer on the metal surface. At the concentration higher than the $\mathrm{CMC}$ value the capacitance value begins to decrease.

The capacitance value can be related to the replacement of the water molecules by the inhibitor molecules, according to the following equation $[15,44]$ :

$\mathrm{Inh}_{(\mathrm{sol})}+\mathrm{nH}_{2} \mathrm{O}_{(\mathrm{ads})} \longrightarrow \mathrm{Inh}_{(\mathrm{ads})}+\mathrm{nH}_{2} \mathrm{O}_{(\mathrm{sol})}$

where $\operatorname{Inh}_{(\mathrm{sol})} / \operatorname{Inh}_{(\mathrm{ads})}$ are inhibitor molecules in the aqueous solution / adsorbed at the metal surface, $\mathrm{H}_{2} \mathrm{O}_{\text {(ads) }} / \mathrm{H}_{2} \mathrm{O}_{\text {(sol) }}$ are water molecules adsorbed at the metal/ in the aqueous solution, $\mathrm{n}$ is the number of water molecules replaced by one inhibitor molecule.

\subsection{Adsorption isotherms}

Adsorption isotherms can be used in determining the mechanism of organoelectrochemical reactions[17]. In the present study, the Langmuir adsorption isotherm was found to be suitable parameter for the correlating the experimental results with a possible mechanism of protection.

Surfactants inhibit the corrosion of stainless steel by adsorbing on the metal, at the metalsolution interface. The adsorption isotherm provides information regarding molecular interaction among the adsorbed molecules themselves as well as molecular interaction with the electrode surface.

A plot of $\mathrm{C} / \theta$ vs $\mathrm{C}$ (surfactant concentration) is presented in Figure 8.

The degree of surface coverage $(\Theta)$ for different concentrations of inhibitor in acidic media have been evaluated by using equation (7) [45-47]: 
$\theta=\frac{I E \%}{100}$

Where IE\% is inhibition efficiency (Table 2).

Linear regression analysis was used to determine the slope value and the interception point. Interception point was compared to the reciprocal of the adsorption equilibrium constant $\left(\mathrm{K}_{\mathrm{ads}}\right)$ and this parameter was used to determine the Gibbs free energy $\left(\Delta \mathrm{G}_{\mathrm{ads}}\right)$ according to the following equation [46]:

$\Delta \mathrm{G}_{\mathrm{ads}}=\mathrm{RT} \ln \left(55.5 \mathrm{~K}_{\mathrm{ads}}\right)$

Where $\mathrm{R}$ is gas constant $8.314 \mathrm{~J}^{*} \mathrm{~mol}^{-1} * \mathrm{~K}^{-1}$, $\mathrm{T}$ is temperature in Kelvin. $\mathrm{K}_{\mathrm{ads}}$ is the adsorption equilibrium constant.

The values of $K_{a d s}, \Delta G_{a d s}$ are reported in Table 4 .

The $\Delta \mathrm{G}_{\mathrm{ads}}$ values provide information about the nature of the process. Negative values indicate that the process is spontaneous of the tested surfactants (TMTN12Br, TMTN12I). Regarding the TMTN12Br $\Delta \mathrm{G}_{\text {ads }}$ values is $-18.98 \mathrm{~kJ} / \mathrm{mol}$. This suggests, that the mechanism of inhibition is based on of physical adsorption. Physical adsorption depends on interactions between lone pair of electrons (from oxygen and nitrogen) and metal surface. In the case of physical adsorption, multi-molecular layers take place. This is because the same type of forces that are responsible for physical adsorption of the first layer of adsorbate, also act between particles approaching the surface of the adsorbent.

In TMTN12I compound the $\Delta \mathrm{G}_{\mathrm{ads}}$ is greater with comparison of TMTN12Br, it's because we distinguish different mechanisms such as chemical and physical adsorption [40]. The reason for this is considered to be because not only lone pair of electrons are responsible for acting TMTN12I as corrosion inhibitor. Also the large counterion (iodine) leads to stronger repulsive forces between iodine and the negatively charged metal plate.

\subsection{Surface morphology}

In order to confirm the corrosion efficiency of two gemini surfactants, the morphology of the surfaces was examined, pre and post immersion, by Scanning Electron Microscopy and Confocal Laser Scanning Microscopy on AISI 304 stainless steel. Micrographs obtained from surfaces exposed to $3 \mathrm{M} \mathrm{HCl}$ solution, at room temperature, with different concentrations of TMTN12Br and TMTN12I are presented in Figure 9.

Here it can be observed that the surface of the metal prior to immersion in the $3 \mathrm{M} \mathrm{HCl}$ solution is free from any detectable signs of corrosion (Figure 9c, 9d). Figure 9b presents the stainless steel in uninhibited solution of $3 \mathrm{M} \mathrm{HCl}$, showing a heavily corroded surface with the presence of pits. When the inhibitors are present in the solution less damage on the surface of the stainless steels is observed (confirming that the tested gemini surfactants reduce the 
corrosion rate of stainless steel in the presence of hydrochloric acid). As explained previously, this process is due to the formation of a protective layer on the metal surface. SEM observation of the sample surfaces after exposure to the different solutions with inhibitors, shows limited attack of the surface and is in agreement with the electrochemical results.

A further measure of the level of corrosion on the surface was made using surface roughness $\left(\mathrm{R}_{\mathrm{a}}\right)$, see Table 5, obtained using confocal laser scanning microscopy. The inhibited steel surface is smoother than the uninhibited surface reflecting the effects of the presence of a protective layer of adsorbed molecules, noatably a reduction in corrosion attack.

\section{Conclusion}

In this study, a cationic gemini surfactants, TMTN12Br was compared to its analogue with a different counterion, TMTN12I, for corrosion inhibition of stainless steel in $3 \mathrm{M} \mathrm{HCl}$ solution using electrochemical techniques. Polarization measurements revealed that both surfactants suppress cathodic and anodic polarization curves and behave as mixed type corrosion inhibitors. However, the gemini surfactant with the iodine counterion out-performs its bromine counterpart with respect to providing corrosion inhibition of stainless steel, in $3 \mathrm{M}$ HCl. TMTN12I proved to be much superior as a corrosion inhibitor and was extremely efficient even at low solution concentrations.

\section{Acknowledgements}

This work was supported by National Centre for Research and Development (Poland; TANGO1/266340/NCBR/2015).

The authors would also like to thank the School of Materials, University of Manchester for providing research facilities.

\section{References}

[1] F.M. Menger, C.A. Littau, Gemini-surfactants: synthesis and properties, J. Am. Chem. Soc. 113 (1991) 1451-1452.

[2] A. Koziróg, B. Brycki, Monomeric and gemini surfactants as antimicrobial agents influence on environmental and reference strains, Acta Biochim. Pol. 62 (2015) 879-883. doi:10.18388/abp.2015_1150.

[3] M. Mahdavian, A.R. Tehrani-Bagha, K. Holmberg, Comparison of a Cationic Gemini Surfactant and the Corresponding Monomeric Surfactant for Corrosion Protection of Mild Steel in Hydrochloric Acid, J. Surfactants Deterg. 14 (2011) 605-613. doi:10.1007/s11743-011-1252-9.

[4] D. Tikariha, K.K. Ghosh, P. Quagliotto, S. Ghosh, Mixed Micellization Properties of Cationic Monomeric and Gemini Surfactants ${ }^{\dagger}$, J. Chem. Eng. Data. 55 (2010) 41624167. doi:10.1021/je100113r.

[5] S. Adak, S. Datta, S. Bhattacharya, R. Banerjee, Role of spacer length in interaction between novel gemini imidazolium surfactants and Rhizopus oryzae lipase, Int. J. Biol. Macromol. 81 (2015) 560-567. doi:10.1016/j.ijbiomac.2015.08.051. 
[6] A.R. Tehrani-Bagha, K. Holmberg, C.G. van Ginkel, M. Kean, Cationic gemini surfactants with cleavable spacer: Chemical hydrolysis, biodegradation, and toxicity, J. Colloid Interface Sci. 449 (2015) 72-79. doi:10.1016/j.jcis.2014.09.072.

[7] A. Pinazo, X. Wen, L. Pérez, M.-R. Infante, E.I. Franses, Aggregation Behavior in Water of Monomeric and Gemini Cationic Surfactants Derived from Arginine, Langmuir. 15 (1999) 3134-3142. doi:10.1021/la9812951.

[8] D. Asefi, M. Arami, N.M. Mahmoodi, Comparing Chain Length Effect of Single Chain and Gemini Surfactants on Corrosion Inhibition of Steel in Acid, in: 2011: pp. 89-101. doi:10.1149/1.3641293.

[9] H. Kunieda, N. Masuda, K. Tsubone, Comparison between Phase Behavior of Anionic Dimeric (Gemini-Type) and Monomeric Surfactants in Water and Water-Oil, Langmuir. 16 (2000) 6438-6444. doi:10.1021/la0001068.

[10] T.A. Camesano, R. Nagarajan, Micelle formation and CMC of gemini surfactants: a thermodynamic model, Colloids Surf. Physicochem. Eng. Asp. 167 (2000) 165-177.

[11] B.E. Brycki, I.H. Kowalczyk, A. Szulc, O. Kaczerewska, M. Pakiet, Multifunctional Gemini Surfactants: Structure, Synthesis, Properties and Applications, in: R. Najjar (Ed.), Appl. Charact. Surfactants, InTech, 2017. doi:10.5772/intechopen.68755.

[12] F.E.-T. Heakal, A.E. Elkholy, Gemini surfactants as corrosion inhibitors for carbon steel, J. Mol. Liq. 230 (2017) 395-407. doi:10.1016/j.molliq.2017.01.047.

[13] A. Tehrani-Bagha, K. Holmberg, Solubilization of Hydrophobic Dyes in Surfactant Solutions, Materials. 6 (2013) 580-608. doi:10.3390/ma6020580.

[14] L.-G. Qiu, Y. Wu, Y.-M. Wang, X. Jiang, Synergistic effect between cationic gemini surfactant and chloride ion for the corrosion inhibition of steel in sulphuric acid, Corros. Sci. 50 (2008) 576-582. doi:10.1016/j.corsci.2007.07.010.

[15] E.E. Oguzie, Y. Li, S.G. Wang, F. Wang, Understanding corrosion inhibition mechanisms-experimental and theoretical approach, RSC Adv. 1 (2011) 866. doi:10.1039/c1ra00148e.

[16] H.M. Abd El-Lateef, M.A. Abo-Riya, A.H. Tantawy, Empirical and quantum chemical studies on the corrosion inhibition performance of some novel synthesized cationic gemini surfactants on carbon steel pipelines in acid pickling processes, Corros. Sci. 108 (2016) 94-110. doi:10.1016/j.corsci.2016.03.004.

[17] M. Abdallah, H.M. Eltass, M.A. Hegazy, H. Ahmed, Adsorption and inhibition effect of novel cationic surfactant for pipelines carbon steel in acidic solution, Prot. Met. Phys. Chem. Surf. 52 (2016) 721-730. doi:10.1134/S207020511604002X.

[18] C. G., A. F., Corrosion Inhibitors - Principles, Mechanisms and Applications, in: M. Aliofkhazraei (Ed.), Dev. Corros. Prot., InTech, 2014. doi:10.5772/57255.

[19] L. Guo, W. Dong, S. Zhang, Theoretical challenges in understanding the inhibition mechanism of copper corrosion in acid media in the presence of three triazole derivatives, RSC Adv. 4 (2014) 41956-41967. doi:10.1039/C4RA04931D.

[20] M. Shimada, H. Kokawa, Z.J. Wang, Y.S. Sato, I. Karibe, Optimization of grain boundary character distribution for intergranular corrosion resistant 304 stainless steel by twin-induced grain boundary engineering, Acta Mater. 50 (2002) 2331-2341.

[21] R.V. Lakshmi, S.T. Aruna, Corrosion protection behaviour of silica-titania hybrid coatings embedded with silica nanoparticles, Surf. Eng. 33 (2017) 467-473. doi:10.1080/02670844.2016.1263431.

[22] A. A., Nanostructure of Materials and Corrosion Resistance, in: M. Aliofkhazraei (Ed.), Dev. Corros. Prot., InTech, 2014. doi:10.5772/57274.

[23] O. Kaczerewska, R. Leiva-Garcia, R. Akid, B. Brycki, Efficiency of cationic gemini surfactants with 3-azamethylpentamethylene spacer as corrosion inhibitors for stainless 
steel in hydrochloric acid, J. Mol. Liq. 247 (2017) 6-13. doi:10.1016/j.molliq.2017.09.103.

[24] O. Kaczerewska, R. Leiva-Garcia, R. Akid, B. Brycki, I. Kowalczyk, T. Pospieszny, Effectiveness of $\mathrm{O}$-bridged cationic gemini surfactants as corrosion inhibitors for stainless steel in $3 \mathrm{M} \mathrm{HCl}$ : Experimental and theoretical studies, J. Mol. Liq. 249 (2018) 1113-1124. doi:10.1016/j.molliq.2017.11.142.

[25] R. Fuchs-Godec, Effect of the Nature of the Counterions of N-alkyl Quaternary Ammonium Salts on Inhibition of the Corrosion Process., Acta Chim. Slov. 54 (2007).

[26] R. Aslam, M. Mobin, S. Zehra, I.B. Obot, E.E. Ebenso, $N, N^{\prime}$-Dialkylcystine Gemini and Monomeric $N$-Alkyl Cysteine Surfactants as Corrosion Inhibitors on Mild Steel Corrosion in $1 \mathrm{M} \mathrm{HCl}$ Solution: A Comparative Study, ACS Omega. 2 (2017) 56915707. doi:10.1021/acsomega.7b00501.

[27] Kabir-ud-Din, P.A. Koya, Z.A. Khan, Conductometric studies of micellization of gemini surfactant pentamethylene-1,5-bis(tetradecyldimethylammonium bromide) in water and water-organic solvent mixed media, J. Colloid Interface Sci. 342 (2010) 340347. doi:10.1016/j.jcis.2009.10.056.

[28] K. Łudzik, K. Kustrzepa, H. Piekarski, M. Jóźwiak, Application of Conductance Study to Analyze Micellization Behavior of Cationic Gemini Surfactants in Water and WaterEthanol Solvent Mixed Media, J. Chem. Eng. Data. 61 (2016) 1047-1053. doi:10.1021/acs.jced.5b00485.

[29] C. Dai, S. Fang, M. Hu, X. He, M. Zhao, X. Wu, S. Yang, Y. Wu, Synthesis, surface adsorption and micelle formation of a class of morpholinium gemini surfactants, J. Ind. Eng. Chem. 54 (2017) 226-233. doi:10.1016/j.jiec.2017.05.037.

[30] R. Zana, Critical micellization concentration of surfactants in aqueous solution and free energy of micellization, Langmuir. 12 (1996) 1208-1211.

[31] K. Bijma, J.B. Engberts, Effect of counterions on properties of micelles formed by alkylpyridinium surfactants. 1. Conductometry and 1H-NMR chemical shifts, Langmuir. 13 (1997) 4843-4849.

[32] S. Pandey, R.P. Bagwe, D.O. Shah, Effect of counterions on surface and foaming properties of dodecyl sulfate, J. Colloid Interface Sci. 267 (2003) 160-166. doi:10.1016/j.jcis.2003.06.001.

[33] N.A. Negm, A.M.A. Sabagh, M.A. Migahed, H.M.A. Bary, H.M.E. Din, Effectiveness of some diquaternary ammonium surfactants as corrosion inhibitors for carbon steel in 0.5M HCl solution, Corros. Sci. 52 (2010) 2122-2132. doi:10.1016/j.corsci.2010.02.044.

[34] M. Finšgar, J. Jackson, Application of corrosion inhibitors for steels in acidic media for the oil and gas industry: A review, Corros. Sci. 86 (2014) 17-41. doi:10.1016/j.corsci.2014.04.044.

[35] P.O. Ameh, N.O. Eddy, Theoretical and experimental studies on the corrosion inhibition potentials of 3-nitrobenzoic acid for mild steel in 0.1 M H2SO4, Cogent Chem. 2 (2016). doi:10.1080/23312009.2016.1253904.

[36] S.M. Shaban, A. Saied, S.M. Tawfik, A. Abd-Elaal, I. Aiad, Corrosion inhibition and Biocidal effect of some cationic surfactants based on Schiff base, J. Ind. Eng. Chem. 19 (2013) 2004-2009. doi:10.1016/j.jiec.2013.03.013.

[37] M.O. Agafonkina, N.P. Andreeva, Y.I. Kuznetsov, S.F. Timashev, Substituted benzotriazoles as inhibitors of copper corrosion in borate buffer solutions, Russ. J. Phys. Chem. A. 91 (2017) 1414-1421. doi:10.1134/S0036024417080027.

[38] M.A. Hegazy, S.S. Abd El-Rehim, E.A. Badr, W.M. Kamel, A.H. Youssif, Mono-, Diand Tetra-Cationic Surfactants as Carbon Steel Corrosion Inhibitors, J. Surfactants Deterg. 18 (2015) 1033-1042. doi:10.1007/s11743-015-1727-1. 
[39] R.H. Tammam, A.M. Fekry, M.M. Saleh, Understanding Different Inhibition Actions of Surfactants for Mild Steel Corrosion in Acid Solution, Int J Electrochem Sci. 11 (2016) 1310-1326.

[40] S.M. Tawfik, A.A. Abd-Elaal, I. Aiad, Three gemini cationic surfactants as biodegradable corrosion inhibitors for carbon steel in $\mathrm{HCl}$ solution, Res. Chem. Intermed. 42 (2016) 1101-1123. doi:10.1007/s11164-015-2076-4.

[41] F. Bentiss, M. Traisnel, M. Lagrenee, The substituted 1, 3, 4-oxadiazoles: a new class of corrosion inhibitors of mild steel in acidic media, Corros. Sci. 42 (2000) 127-146.

[42] Y.-J. Tan, S. Bailey, B. Kinsella, An investigation of the formation and destruction of corrosion inhibitor films using electrochemical impedance spectroscopy (EIS), Corros. Sci. 38 (1996) 1545-1561.

[43] M.P. Desimone, G. Grundmeier, G. Gordillo, S.N. Simison, Amphiphilic amido-amine as an effective corrosion inhibitor for mild steel exposed to $\mathrm{CO} 2$ saturated solution: Polarization, EIS and PM-IRRAS studies, Electrochimica Acta. 56 (2011) 2990-2998. doi:10.1016/j.electacta.2011.01.009.

[44] N.O. Eddy, E.E. Ebenso, Corrosion inhibition and adsorption characteristics of tarivid on mild steel in $\mathrm{H} 2 \mathrm{SO} 4$, J. Chem. 7 (2010) S442-S448.

[45] I. Ahamad, M.A. Quraishi, Bis (benzimidazol-2-yl) disulphide: An efficient water soluble inhibitor for corrosion of mild steel in acid media, Corros. Sci. 51 (2009) 20062013. doi:10.1016/j.corsci.2009.05.026.

[46] M.A. Hegazy, M. Abdallah, H. Ahmed, Novel cationic gemini surfactants as corrosion inhibitors for carbon steel pipelines, Corros. Sci. 52 (2010) 2897-2904. doi:10.1016/j.corsci.2010.04.034.

[47] N.A. Negm, Y.M. Elkholy, M.K. Zahran, S.M. Tawfik, Corrosion inhibition efficiency and surface activity of benzothiazol-3-ium cationic Schiff base derivatives in hydrochloric acid, Corros. Sci. 52 (2010) 3523-3536. doi:10.1016/j.corsci.2010.07.001.

\section{Caption of Figures}

Figure 1. The chemical structure of synthesized cationic gemini surfactants.

Figure 2. Plot of specific conductivity $(\kappa)$ versus concentration of TMTN12I in water at 25 ${ }^{\circ} \mathrm{C}$ and pressure $0.1 \mathrm{MPa}$.

Figure 3. Open circuit potential - time curves for stainless steel electrode immersed in $3 \mathrm{M}$ $\mathrm{HCl}$ at room temperature in the absence and presence of different concentration of the gemini surfactants.

Figure 4. Polarization curves for AISI 304 in $3 \mathrm{M} \mathrm{HCl}$ with and without different concentrations of TMTN12Br at room temperature.

Figure 5. Polarization curves for AISI 304 in $3 \mathrm{M} \mathrm{HCl}$ with and without different concentrations of TMTN12I at room temperature.

Figure 6. Nyquist plot for stainless steel in $3 \mathrm{M} \mathrm{HCl}$, after $24 \mathrm{~h}$ immersion, in the presence and absence of selected inhibitors (at their most effective concentrations - above CMC) with fitting curves.

Figure 7. The equivalent circuit for the system studied.

Figure 8. Langmuir isotherm adsorption model of (a) TMTN12I and (b) TMTN12Br for stainless steel in $3 \mathrm{M} \mathrm{HCl}$. 
Figure 9. SEM micrographs of stainless steel surface (a) before immersion (b) after $24 \mathrm{~h}$ immersion in $3 \mathrm{M} \mathrm{HCl}$ (c) after $24 \mathrm{~h}$ immersion in $3 \mathrm{M} \mathrm{HCl}$ with TMTN12Br $1.5 \mathrm{Mm}$ (d) after $24 \mathrm{~h}$ immersion in $3 \mathrm{M} \mathrm{HCl}$ with TMTN12I $1.5 \mathrm{Mm}$

\section{Caption of Tables}

Table 1. Critical micelle concentration (CMC), counterion binding parameter $(\beta)$ and Gibbs free energy of micellization $\left(\Delta \mathrm{G}^{\circ}{ }_{\text {mic }}\right)$ of gemini surfactants obtained from conductivity measurements.

Table 2. Electrochemical parameters calculate from potentiodynamic curves of AISI 304 specimen in $3 \mathrm{M} \mathrm{HCl}$ with and without different concentrations of TMTN12Br and TMTN12I after $24 \mathrm{~h}$ immersion at room temperature.

Table 3. Inhibitor efficiency values based upon EIS parameters, for corrosion of stainless steel in $3 \mathrm{M} \mathrm{HCl}$ in the absence and presence of different concentrations of the selected surfactants (after $24 \mathrm{~h}$ immersion).

Table 4. Data obtained from Langmuir isotherm model for TMTN12I and TMTN12Br for stainless steel in $3 \mathrm{M} \mathrm{HCl}$.

Table 5. The roughness of stainless steel samples before and after (24h) immersion in $3 \mathrm{M}$ $\mathrm{HCl}$ and with or without tested compounds. 
Table 1

\begin{tabular}{cccc}
\hline & $\mathbf{C M C}[\mathbf{m M}]$ & $\boldsymbol{\beta}$ & $\boldsymbol{\Delta G}^{\circ} \mathbf{m i c}[\mathbf{k J} / \mathbf{m o l}]$ \\
\hline TMTN12I & $1.48 \pm 0.02$ & 0.84 & -22.53 \\
\hline TMTN12Br & $1.48 \pm 0.01$ & 0.45 & -16.21 \\
\hline
\end{tabular}


Table 2

\begin{tabular}{cccccc}
\hline & $\begin{array}{c}\text { Concentration of } \\
\text { surfactant }[\mathbf{m M}]\end{array}$ & $\mathbf{E}_{\mathbf{c o r r}}[\mathbf{m V}]$ & $\mathbf{i}_{\text {corr }}\left[\boldsymbol{\mu A} / \mathbf{c m}^{2}\right]$ & $\begin{array}{c}\text { CR } \\
{[\mathbf{m m} / \mathbf{y} \text { ear] }}\end{array}$ & $\begin{array}{c}\text { Inhibition efficiency } \\
{[\%]}\end{array}$ \\
\hline \multirow{2}{*}{ 3M HCl } & 0 & $-316 \pm 1$ & $1807.47 \pm 0.51$ & $20.77 \pm 0.45$ & - \\
\hline \multirow{3}{*}{ TMTN12I } & 0.015 & $-291 \pm 2$ & $107.24 \pm 0.45$ & $1.24 \pm 0.03$ & 94 \\
\cline { 2 - 6 } & 0.15 & $-270 \pm 1$ & $57.67 \pm 0.55$ & $0.66 \pm 0.07$ & 97 \\
\cline { 2 - 6 } & $\mathbf{1 . 5}$ & $\mathbf{- 2 2 7} \pm 1$ & $\mathbf{3 6 . 5 5} \pm 0.34$ & $\mathbf{0 . 2 8} \pm 0.09$ & $\mathbf{9 9}$ \\
\hline & 3 & $-224 \pm 1$ & $24.47 \pm 0.22$ & $0.42 \pm 0.06$ & 98 \\
\cline { 2 - 6 } TMTN12Br & 0.015 & $-292 \pm 1$ & $95.00 \pm 0.34$ & $1.09 \pm 0.12$ & 95 \\
\cline { 2 - 6 } & 0.15 & $-294 \pm 1$ & $417.68 \pm 0.28$ & $4.81 \pm 0.07$ & 77 \\
\cline { 2 - 6 } & $\mathbf{1 . 5}$ & $\mathbf{- 2 9 0} \pm 1$ & $\mathbf{5 5 . 7 4} \pm 0.21$ & $\mathbf{1 . 0 0} \pm 0.09$ & $\mathbf{9 7}$ \\
\hline
\end{tabular}


Table 3

\begin{tabular}{|c|c|c|c|c|}
\hline & $\begin{array}{l}\text { Concentration of } \\
\text { surfactant }[\mathrm{mM}]\end{array}$ & $\mathbf{R}_{\mathrm{ct}}\left[\Omega \mathrm{cm}^{2}\right]$ & $\mathrm{C}_{\mathrm{dl}}\left[\mu \mathrm{F} / \mathrm{cm}^{2}\right]$ & $\begin{array}{c}\text { Inhibition efficiency } \\
{[\%]}\end{array}$ \\
\hline $3 \mathrm{M} \mathrm{HCl}$ & $\mathbf{0}$ & $29 \pm 1.22$ & $7296 \pm 0.22$ & - \\
\hline \multirow{4}{*}{ TMTN12I } & 0.015 & $218 \pm 4.52$ & $615 \pm 1.23$ & 87 \\
\hline & 0.15 & $396 \pm 5.54$ & $304 \pm 1.65$ & 93 \\
\hline & 1.5 & $709 \pm 6.23$ & $407 \pm 1.12$ & 96 \\
\hline & 3 & $697 \pm 4.32$ & $220 \pm 1.42$ & 96 \\
\hline \multirow{4}{*}{ TMTN12Br } & 0.015 & $248 \pm 3.32$ & $4594 \pm 2.42$ & 88 \\
\hline & 0.15 & $81 \pm 3.23$ & $5459 \pm 2.87$ & 64 \\
\hline & 1.5 & $234 \pm 5.34$ & $2838 \pm 2.42$ & 87 \\
\hline & 3 & $322 \pm 4.65$ & $3821 \pm 1.78$ & 91 \\
\hline
\end{tabular}


Table 4

\begin{tabular}{ccccc}
\hline & slope & $\mathbf{R}^{2}$ & $\mathbf{K}_{\text {ads }} * \mathbf{1 0}^{3}\left[\mathbf{d m}^{\mathbf{3}} / \mathbf{m o l}\right]$ & $\Delta \mathbf{G}_{\text {ads }}[\mathbf{k J} / \mathbf{m o l}]$ \\
\hline TMTN12I & 1.0199 & 1.0000 & 1.315 & -27.16 \\
TMTN12Br & 1.0196 & 0.9998 & 0.038 & -18.98 \\
\hline
\end{tabular}


Table 5

HCl

3M

$\mathbf{R}_{a}[\boldsymbol{\mu m}]$

Before immersion
TMTN12Br

$1.5 \mathrm{mM}$

$1.5 \mathrm{mM}$ 


\section{Highlights}

$\square$ New surfactants with polyamine platform were synthesized.

$\square$ Critical Micelle Concentration was determined for two gemini surfactants with different counterion.

$\square$ Polarisation and EIS measurement were used for analysis.

$\square$ The surface of AISI 304 specimen was characterized using SEM and CLSM. 


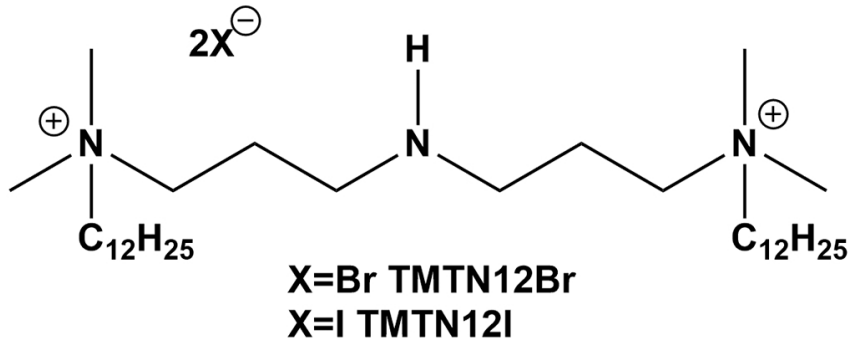

Figure 1 


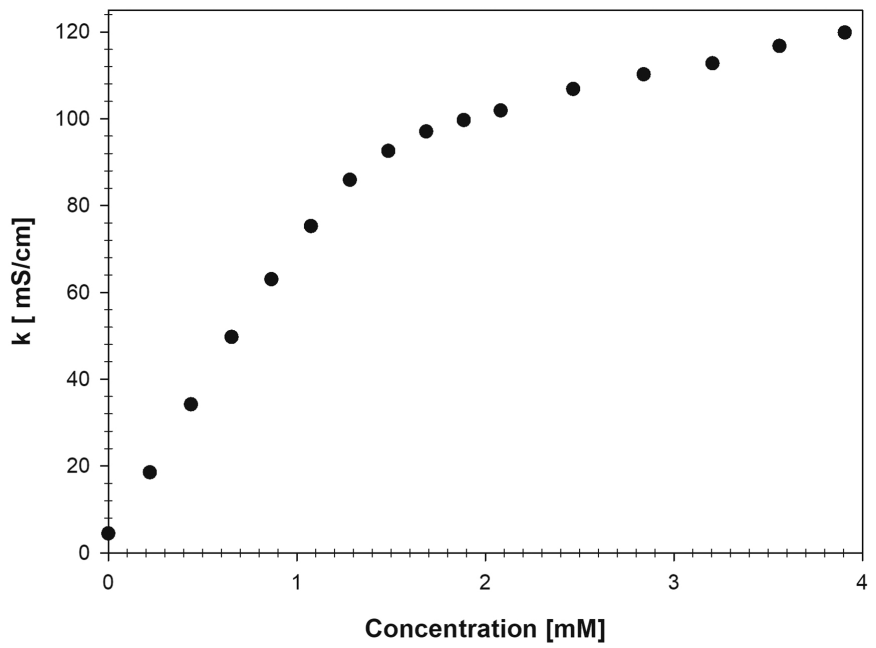

Figure 2 


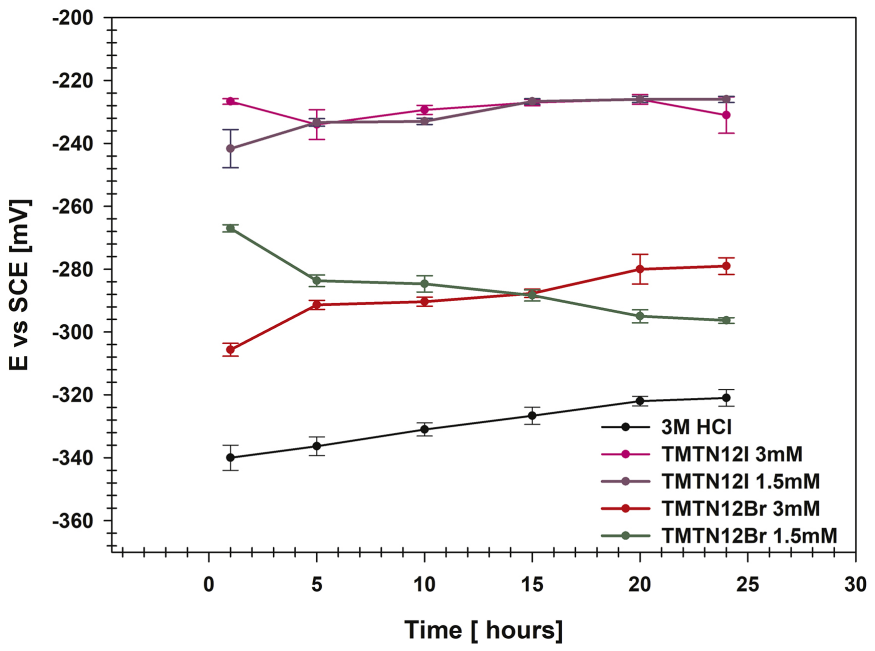

Figure 3 


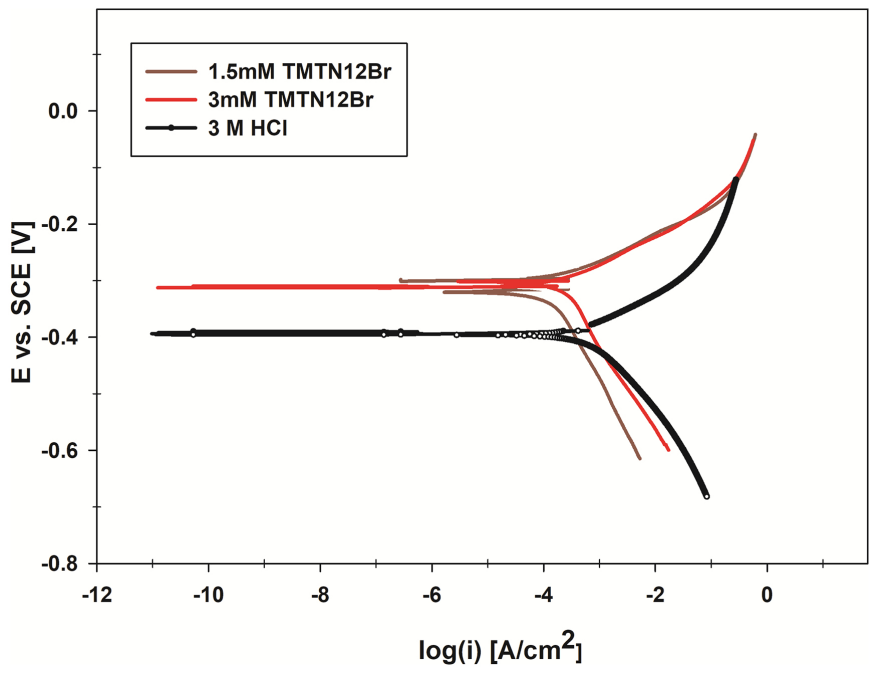

Figure 4 


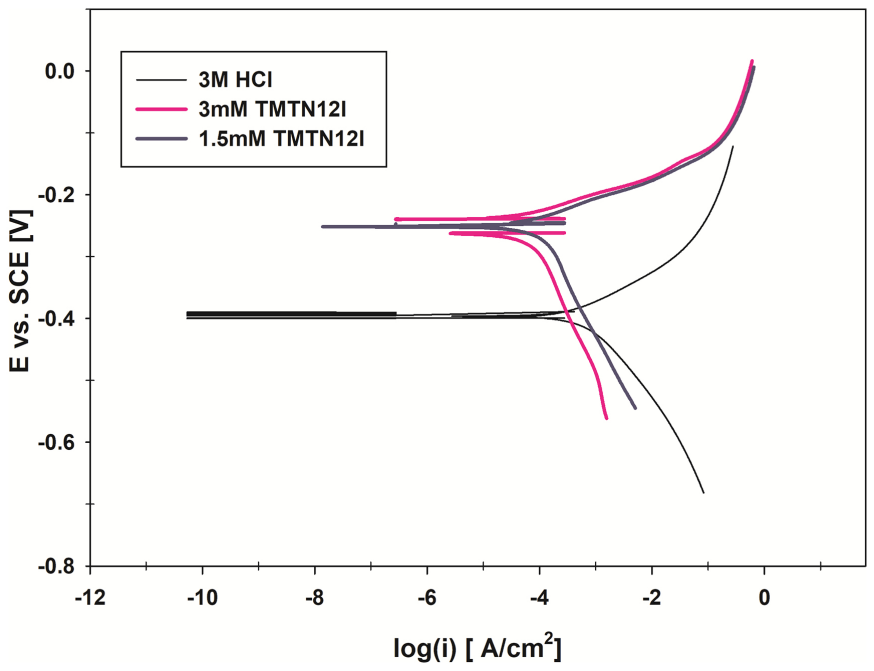

Figure 5 


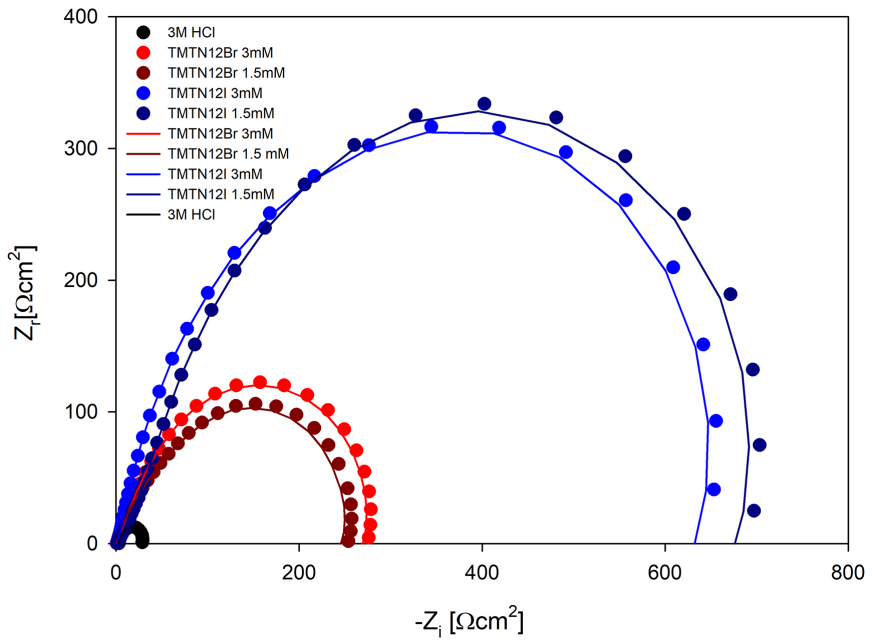

Figure 6 


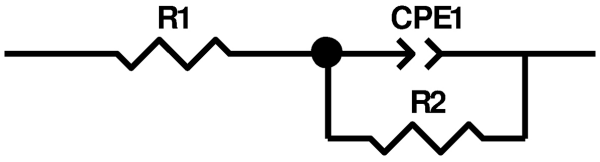

Figure 7 

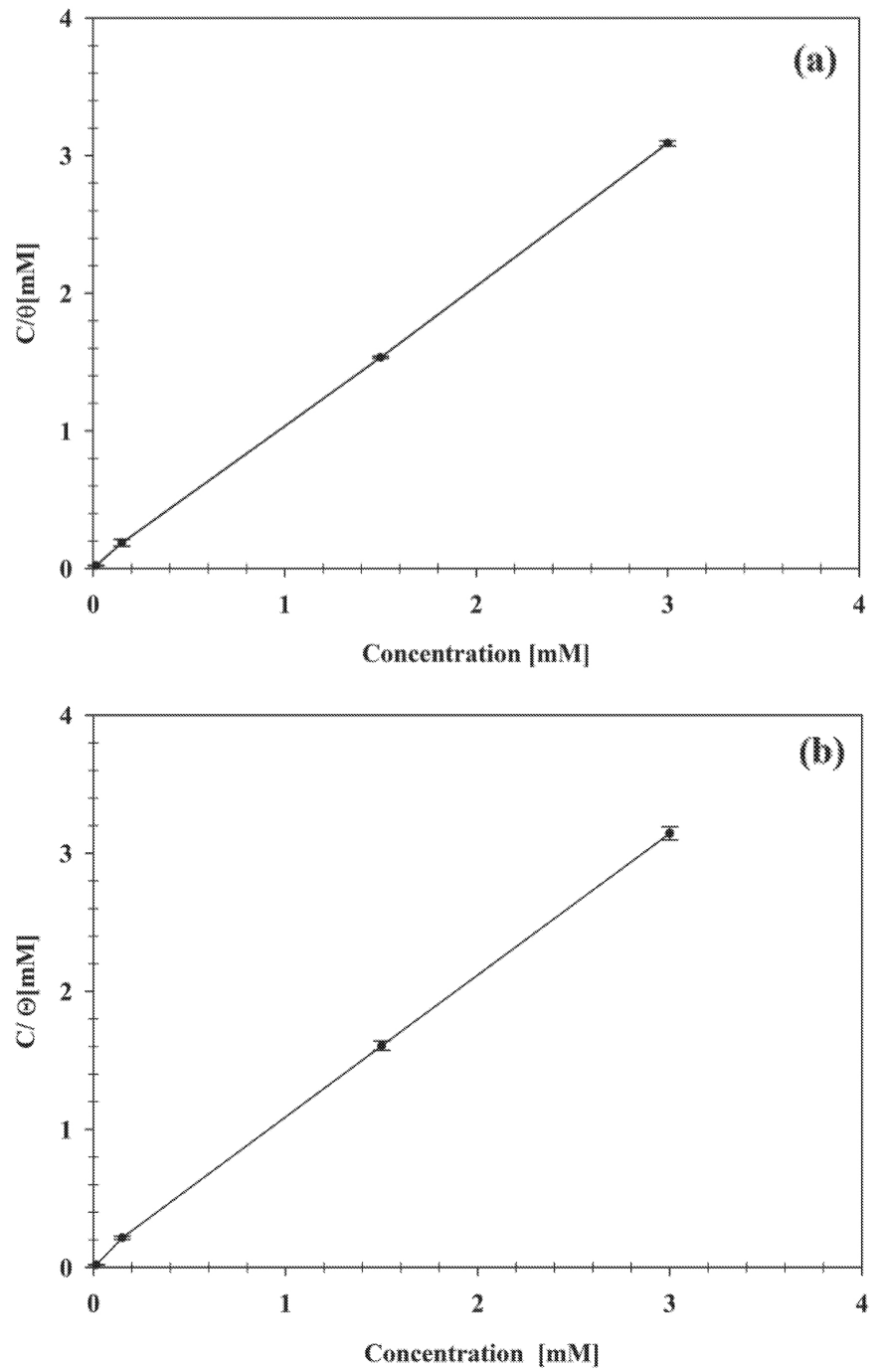

Figure 8 

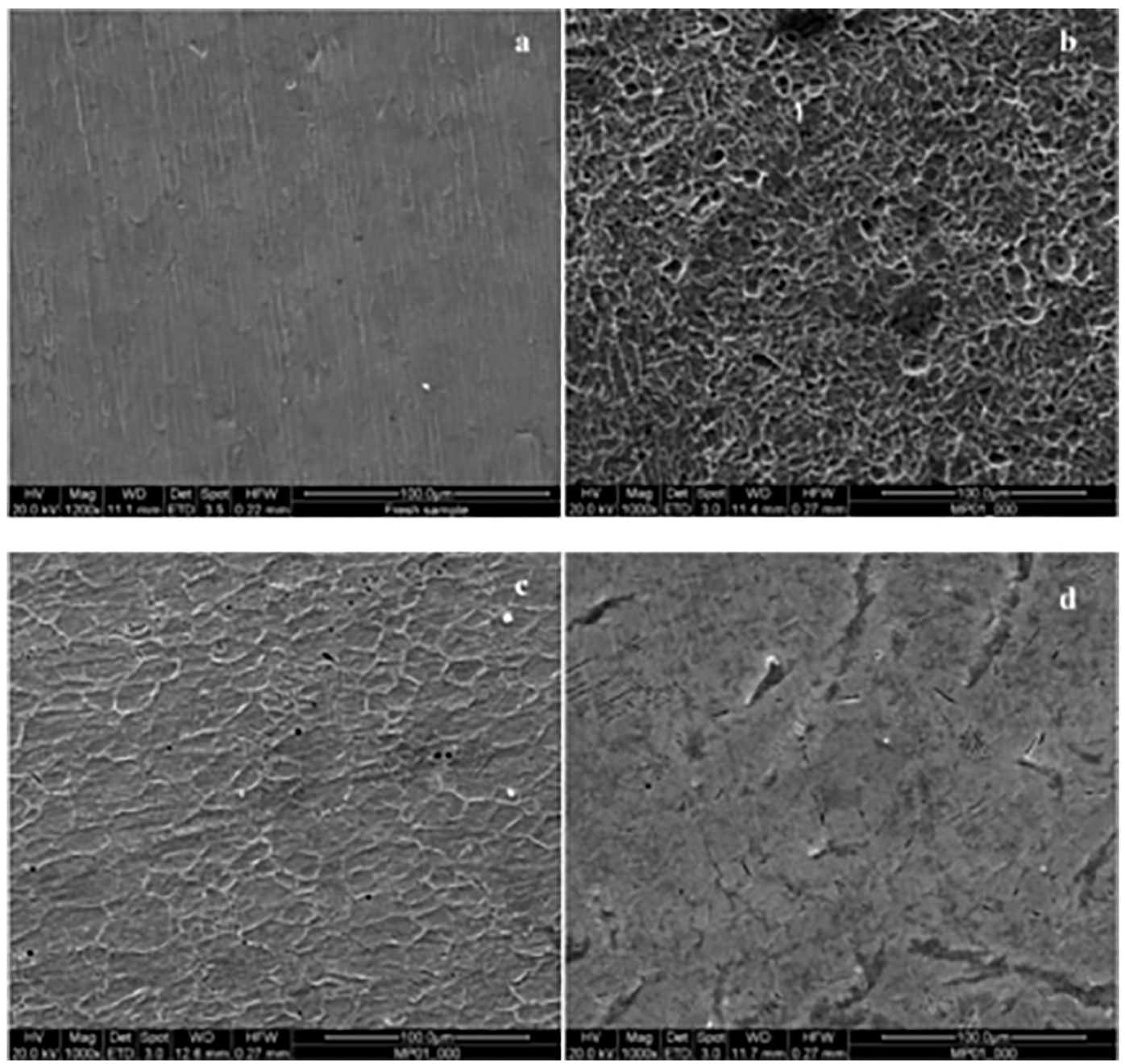

Figure 9 